DEPÓSITO LEGAL ZU2020000153

Esta publicación científica en formato digital

es continuidad de la revista impresa

ISSN 0041-8811

E-ISSN 2665-0428

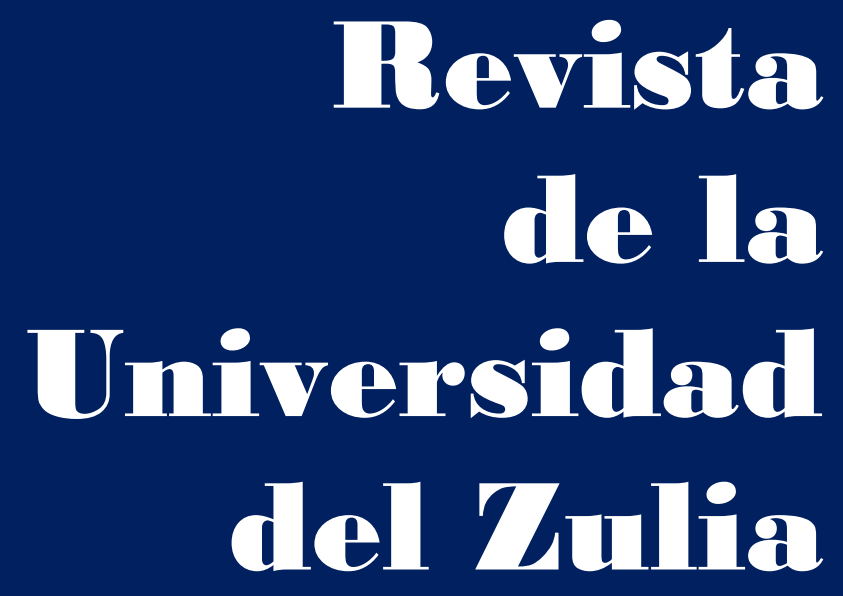

Fundada en 1947

por el Dr. Jesús Emrique Lossada

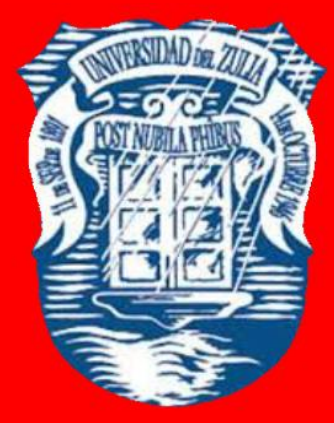

Ciencias

Sociales

y Arte

Año $12 \quad N^{\circ} 34$

Septiembre - Diciembre 2021

Tercera Época

Maracaibo-Veneruela 
REVISTA DE LA UNIVERSIDAD DEL ZULIA. $3^{a}$ época. Año 12 N 34, 2021

Danil Alekseevich Zyukin et al// Poverty in Russia as the main threat to economic security ... 261-281

DOI: http://dx.doi.org/10.46925//rdluz.34.16

\title{
Poverty in Russia: economic and social implications
}

\author{
Danil Alekseevich Zyukin * \\ Alexey Anatolievich Golovin ** \\ Ruslan Yakovlevich Vakulenko *** \\ Olga Vladimirovna Pigoreva **** \\ Elena Nikolaevna Nozdracheva ***** \\ Olga Viktorovna Khorlyakova ******
}

ABSTRACT

The purpose of the research is to analyze of poverty in Russia as the most important social problem of our time. The methodology of the study includes an assessment of the dynamics of socio-economic indicators in Russia in the period 2015-2020, as well as a comparison with European countries. It is shown that the problem of poverty is still one of the most pressing and urgent for modern Russia. Despite the outlined positive dynamics in the poverty level of the country's population in 2018-2019, there was a decline again in 2020, due to the deterioration of the socio-economic situation against the backdrop of the Coronavirus pandemic. As a result, the effectiveness of the earlier measures in the framework of social policy has practically disappeared, and the poverty level has practically reached 13\%. The systemic lack of financial support for such critical sectors as education and health care has contributed to a series of cuts in order to save limited resources. A comparative analysis of the main socio-economic indicators in Russia and European countries made it possible to reveal the presence of significant differentiation, since Russia occupies the last positions among the compared countries in terms of basic social indicators.

KEY WORDS: social policy; standard of living; poverty alleviation; income; wealth.

* Senior Researcher, Kursk State Agricultural Academy named after I.I. Ivanov. ORCID: https://orcid.org/0000-0001-8118-2907. E-mail: nightingale46@rambler.ru

** Associate Professor, Head of the Department of Economic Theory, Regional Studies and Legal Regulation of the Economy, Kursk Academy of State and Municipal Service. ORCID: https://orcid.org/0000-0003-49622022. E-mail: dr.golovin2013@yandex.ru

*** Associate Professor, Head of the Department World Economy and Informatics Nizhny Novgorod State Linguistic University named after N. A. Dobrolyubov. ORCID: https://orcid.org/0000-0002-1483-9734. Email: vakulenko_r@rambler.ru

**** Professor of the Department of Economics, Management and Humanities, Kursk State Agricultural Academy named after I.I. Ivanov. ORCID: https:/orcid.org/0000-0003-3565-1746. E-mail: ovpigoreva@yandex.ru

*****Associate Professor in Economics, Associate Professor of the Department of Economics and Accounting Kursk State University. ORCID: https://orcid.org/0000-0002-0783-9453. E-mail: nen.kgu@mail.ru

******Candidate of Pharmaceutical Sciences, Associate Professor of the Department of Biological Chemistry, Kursk State Medical University of the Ministry of Health of Russia. ORCID: https://orcid.org/0000-00018918-7606. E-mail: khorlykova@mail.ru 


\section{La pobreza en Rusia: implicaciones económicas y sociales}

RESUMEN

El propósito de la investigación es analizar la pobreza en Rusia como el problema social más importante de nuestro tiempo. La metodología del estudio incluye una evaluación de la dinámica de los indicadores socioeconómicos en Rusia en el período 2015-2020, así como una comparación con los países europeos. Se demuestra que el problema de la pobreza sigue siendo uno de los más apremiantes y urgentes para la Rusia moderna. A pesar de la dinámica positiva delineada en el nivel de pobreza de la población del país en 2018-2019, hubo una disminución nuevamente en 2020, debido al deterioro de la situación socioeconómica en el contexto de la pandemia de coronavirus. Como resultado, la efectividad de las medidas anteriores en el marco de la política social prácticamente ha desaparecido y el nivel de pobreza prácticamente ha alcanzado el $13 \%$. La falta sistémica de apoyo financiero para sectores tan críticos como la educación y la salud ha contribuido a una serie de recortes para ahorrar recursos limitados. Un análisis comparativo de los principales indicadores socioeconómicos de Rusia y los países europeos permitió revelar la presencia de una diferenciación significativa, ya que Rusia ocupa las últimas posiciones entre los países comparados en términos de indicadores sociales básicos.

PALABRAS CLAVE: política social; estándar de vida; mitigación de la pobreza; ingresos; riqueza.

\section{Introduction}

Ensuring sustainable socio-economic development is one of the most important tasks facing each state at the present stage. The key problem that has become more acute in recent years in Russia has been the growing poverty of the population. This phenomenon is complex, because it is determined by both economic and social reasons, and also carries a wide range of consequences of different nature. Given the fundamental impact on the state of society and the harmonious development of the economy, the problem of poverty becomes the main threat to the economic security of the country. The consequences of the decline in the real income level of Russians and the progress in increasing the share of low-income citizens are of significant importance for the stability of the current political system of the country before the elections to the "State Duma".

The importance of creating a favorable social environment is to reduce social tension among the population, as well as to increase the attractiveness of a particular area for living 
and the flow of investment (Gnangnon, 2021). The global socio-economic situation in recent years is developing unfavorably: a series of economic crises, political and military conflicts, as well as a worsening epidemiological situation and the coronavirus pandemic have dealt a significant economic blow, inevitably provoking a deterioration in the social situation of the population (Hussain et al., 2021; Datt et al, 2020). As a result, there has been an increase in socio-economic differentiation both between countries and within them, which has actualized the task of maintaining an optimal level of well-being of the population.

In the context of acute political processes within the country against the background of elections and relations with the world society against the background of sanctions, as well as the characteristic consequences for the economy and society as a result of the impoverishment of the population, we define poverty as the main threat to Russia's economic security. Therefore, the purpose of the study was to assess the indicators that characterize poverty as a socio-economic phenomenon.

\section{Materials and methods}

In the course of the study, using data from the statistical collection "Russia in Numbers" (2021), the main indicators of the standard of living of the population in Russia in the period 2015-2020 are considered. The number and proportion of the poor were selected as the main criteria for assessing the level of poverty, which makes it possible to assess the change not only in the absolute number of people living below the poverty line, but also makes it possible to assess the overall effectiveness of social policy aimed at reducing the level of poverty in the country. Also, an assessment of the dynamics of the average per capita income of the Russian population, reflecting the nominal growth in welfare, is given, and the change in real disposable income, expressed as a percentage of the previous year, is considered, which makes it possible to assess the real trends in the change in the population's income in the period under study, not related to inflationary processes in the economy.

Based on the data of the analytical report for the Central Bank of the Russian Federation "Measurement of inflation expectations and consumer sentiment based on public opinion polls" (June 2021), an assessment of the position of the population regarding the change in its financial situation and the rise in prices in the economy was carried out in the period from January 2019 to April 2021 quarterly. The exception is the period April-July 2020, 
REVISTA DE LA UNIVERSIDAD DEL ZULIA. $3^{\text {a }}$ época. Año 12 N 34, 2021

Danil Alekseevich Zyukin et al// Poverty in Russia as the main threat to economic security ... 261-281

DOI: http://dx.doi.org/10.46925//rdluz.34.16

when, due to the deteriorating epidemiological situation, surveys were not carried out, in connection with which the data for March and August 2020 were considered. The survey was conducted on a sample of 2,021 adults living in 55 regions of the Russian Federation. The interview was conducted at the place of residence in the "face-to-face" mode, while the statistical error of the results was within 3.3\%. The study of the position of the population regarding their own financial situation and the level of prices in the economy makes it possible to assess personal feelings about the changes in the level and cost of living in recent years.

The assessment of the state of the social sphere in Russia was carried out on the basis of the dynamics of the development of the health care system and education. In the field of health care, the dynamics of the number and provision of the population with outpatient and inpatient medical organizations has been analyzed, which makes it possible to assess the level of accessibility of medical care for the population at each stage of medical care. In the field of education, the assessment was made in the context of the dynamics of the number of educational institutions of different levels - schools, organizations of secondary vocational and higher education in total and in the context of forms of ownership. The results of the study make it possible to assess the development of the most important areas of the social sphere, which reflects the level of accessibility of social infrastructure and the quality of life of the population as a whole.

The study also provides a comparative analysis of the standard of living in Russia and 9 European countries as of 2020 based on a number of indicators. The following were selected as key indicators: the size of the subsistence minimum, the size of the minimum and average wages per month, expressed in US dollars; unemployment and poverty rates as a percentage; and quality of life and human development indices. Evaluation of the selected indicators in Russia in comparison with European countries makes it possible to comprehensively assess the existing standard of living in the country in the context of the problem of poverty. The study of the level of poverty in Russia as a social problem of our time was carried out on the basis of a number of methods and approaches, including analysis of dynamics, comparative and logical analysis.

\section{Results}


REVISTA DE LA UNIVERSIDAD DEL ZULIA. $3^{a}$ época. Año 12 N 34, 2021

Danil Alekseevich Zyukin et al// Poverty in Russia as the main threat to economic security ... 261-281

DOI: http://dx.doi.org/10.46925//rdluz.34.16

The total population below the poverty line in Russia at the beginning of the period under review was 19.5 million people, which is equal to $13.3 \%$ of the total population in the country. In the period 2016-2019, there is a steady trend towards a decrease in both the number and the share of the poor population in the country. At the same time, the trend has been increasing since 2018, when the number of poor people amounted to 18.4 million people, which is equal to $12.6 \%$. The lowest value of the indicators can be identified in 2019 , when the number of people below the poverty line fell to 18.1 million. people, and their share is up to $12.3 \%$, which is more than $7 \%$ higher than the data of 2015 . At the same time, in 2020, associated with the beginning of the coronavirus pandemic, there was an increase in the number of poor people in the Russian Federation to 18.8 million people, which is equal to $12.9 \%$ of the total population in the country. The increase in indicators compared to the level of the previous year was 3.9\% and $4.9 \%$, respectively, due to the deterioration of the economic situation in the country, as a result of which there was a decrease in the income of the population (Figure 1).

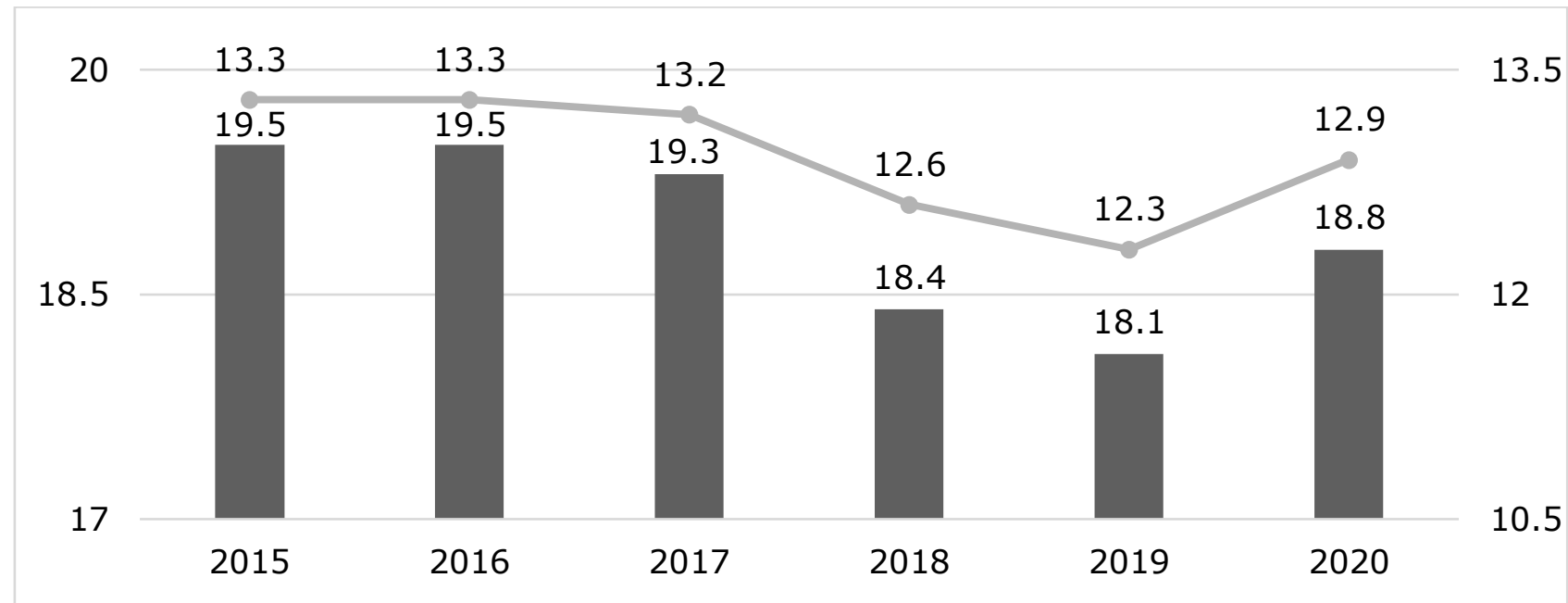

Population with monetary incomes below the subsistence level, $\mathrm{mln}$. - Poverty rate, \% Source: compiled by the authors on the basis of data from Russia in numbers (2021).

Figure 1. Dynamics of the number and share of the poor population in Russia in 20152020.

The average per capita income of the population in national currency is steadily growing in the period under study, reaching 35.7 thousand rubles by 2020 , which is $17 \%$ higher than the level of 2015, when the indicator was 30.5 thousand rubles. At the same time, the highest rates of growth in the average per capita income of the population of the Russian 
REVISTA DE LA UNIVERSIDAD DEL ZULIA. $3^{a}$ época. Año 12 N 34, 2021

Danil Alekseevich Zyukin et al// Poverty in Russia as the main threat to economic security ... 261-281

DOI: http://dx.doi.org/10.46925//rdluz.34.16

Federation have been observed in recent years, starting in 2018, when the indicator reached 33.3 thousand rubles. Despite the nominal stable growth of average per capita income, the assessment of the dynamics of real per capita income showed a wavelike character of the change in the indicator. In the period 2015-2017, the increase in average per capita income had a negative trend, as evidenced by the value of the indicator not exceeding $100 \%$. At the same time, the largest decline can be noted in 2016 and it is 5.8\%. In 2018-2019. there was a positive trend, as a result of which in 2018 the increase in average per capita income was $0.4 \%$, and amounted to $1 \%$ in 2019. In 2020, there is again a decrease in the average per capita income of the population by $3 \%$ compared to the level of the previous year, which is associated with the deterioration of the economic situation in the country during the pandemic (Figure 2).

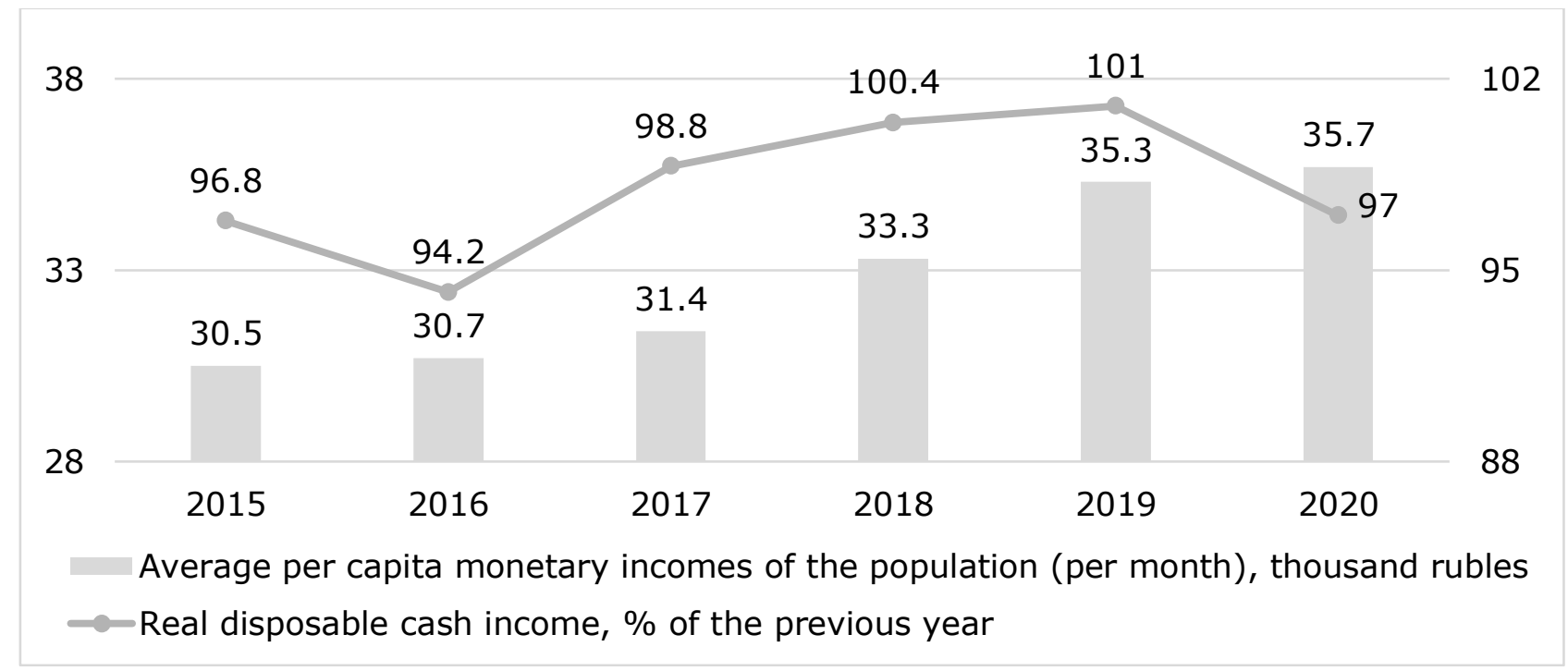

Source: compiled by the authors on the basis of data from Russia in numbers (2021).

Figure 2. Dynamics of average per capita money income and real disposable income of the population in Russia in 2015-2020.

According to the results of a sociological survey, the material situation of the majority of the country's population (more than 50\%) has not changed since January 2019, however, this indicator varied within 52-59\% in the period from January 2019 to March 2020, and decreased to 51\% already in August 2020. Despite the positive dynamics of growth in the share of the population with the same income level in October 2020 - January 2021, its share decreased to $51-50 \%$ in April-June 2021, which is the lowest value. At the same time, there is an increase in the proportion of the population whose financial situation decreased in the 
REVISTA DE LA UNIVERSIDAD DEL ZULIA. $3^{a}$ época. Año 12 N 34, 2021 Danil Alekseevich Zyukin et al// Poverty in Russia as the main threat to economic security ... 261-281

DOI: http://dx.doi.org/10.46925//rdluz.34.16

study period, especially in August 2020, when the proportion of such a population increased to 39\%. Despite the improvement in the situation in October 2020 and January 2021, the share of the population increased again with a deterioration in the financial situation to $38 \%$. in April 2021. In turn, the proportion of the population, whose financial situation has improved, varied from January 2019 to March 2020, being in the range of 11-14\%. However, there is a decrease in this indicator to 9\% already in August 2020, and to 10\% already in August 2020. As a result, it can be concluded that the situation with the material situation of the population was more stable in the period until August 2020, and in recent periods, due to the coronavirus pandemic, there was a general deterioration in the material situation of the population; at the same time, the variation by quarters increased due to the general socioeconomic instability (Figure 3).

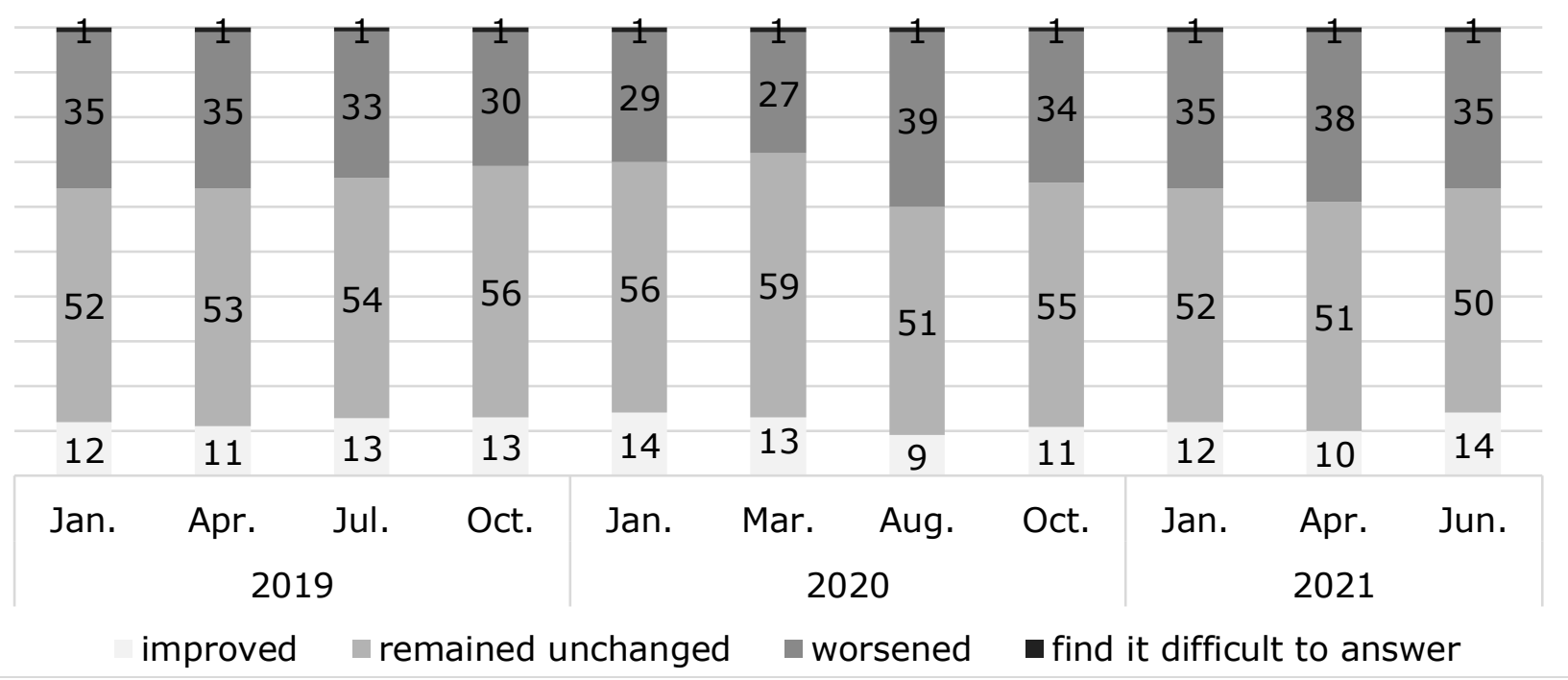

Source: compiled by the authors on the basis of data measuring inflation expectations and consumer sentiment based on public opinion polls for June 2021.

Figure 3. Assessment of changes in the material situation of the population of Russia based on a sociological survey\%.

At the same time, according to the population, a significant increase in prices in the period from January 2019 to October 2020 was noted by 45\% -34\%, and since January 2021 this indicator has exceeded 50\% and tends to grow to $58 \%$ by the end of the surveyed period with a simultaneous decrease in the proportion of the population, who have an opinion about a less significant increase in prices. In 2019-2020, moderate growth was noted by slightly more than $40 \%$ of the population, and since January there was a decrease in the indicator to 
REVISTA DE LA UNIVERSIDAD DEL ZULIA. $3^{a}$ época. Año 12 N 34, 2021

Danil Alekseevich Zyukin et al// Poverty in Russia as the main threat to economic security ... 261-281

DOI: http://dx.doi.org/10.46925//rdluz.34.16

$33 \%$, and to $29 \%$ by the end of the period under review. At the same time, a slight increase in prices in 2019-2020 was highlighted by about 15\% of respondents, and in 2021 the indicator decreased to less than $10 \%$. As a result, it can be noted that in 2021, in the opinion of the population, there was an increase in the growth of prices for goods and products compared to previous periods, which is due to the deterioration of the economic situation (Figure 4).

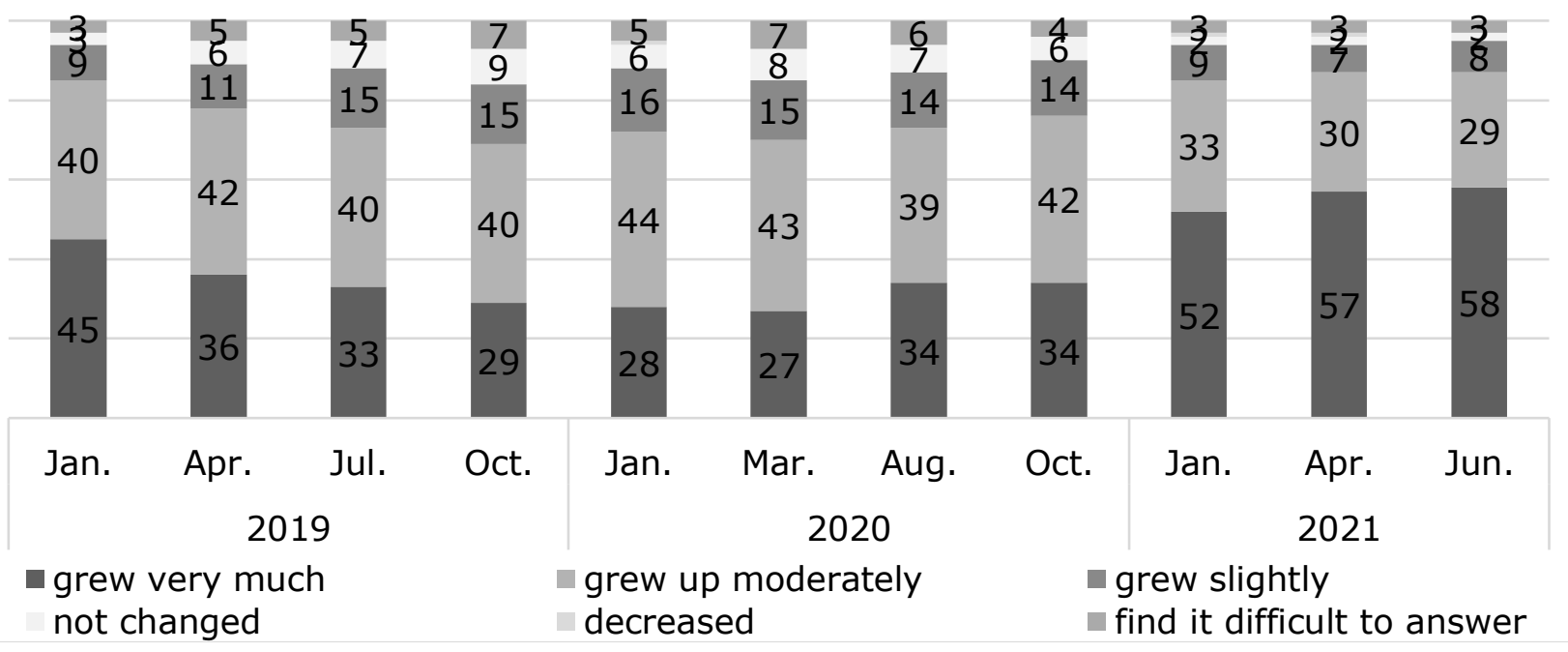

Source: compiled by the authors on the basis of data measuring inflation expectations and consumer sentiment based on public opinion polls for June 2021.

Figure 4. Estimation of price growth over the past month according to the opinion of the Russian population based on a sociological survey\%.

At the present stage, the development of the country's social sphere, mainly healthcare and education, is of great importance, which also largely determines the level and quality of life of the population. Important social indicators such as morbidity and mortality, as well as the health of the nation in general, depend on the efficiency of the functioning of the health care system. In turn, the role of the education sector is to form a high level of literacy of the population, which contributes, among other things, to an increase in the scientific potential of the country. The high level of development and effective functioning of these sectors of the social sphere is aimed at the formation of large human capital and is inextricably linked with the standard of living and well-being of the population (Zyukin et al., 2020a; Zyukin 2 et al., 2020b).

An assessment of the main indicators of the development of the healthcare system in Russia revealed that in the last 6 years there has been a tendency for the number of outpatient clinics to grow by $14 \%$ to 21.2 thousand, while the number of hospitals has decreased to 5.1 
REVISTA DE LA UNIVERSIDAD DEL ZULIA. $3^{a}$ época. Año 12 N 34, 2021

Danil Alekseevich Zyukin et al// Poverty in Russia as the main threat to economic security ... 261-281

DOI: http://dx.doi.org/10.46925//rdluz.34.16

thousand. This is due to optimization processes in healthcare and the active development of primary care as the main element of the medical care system in Russia (Figure 5).

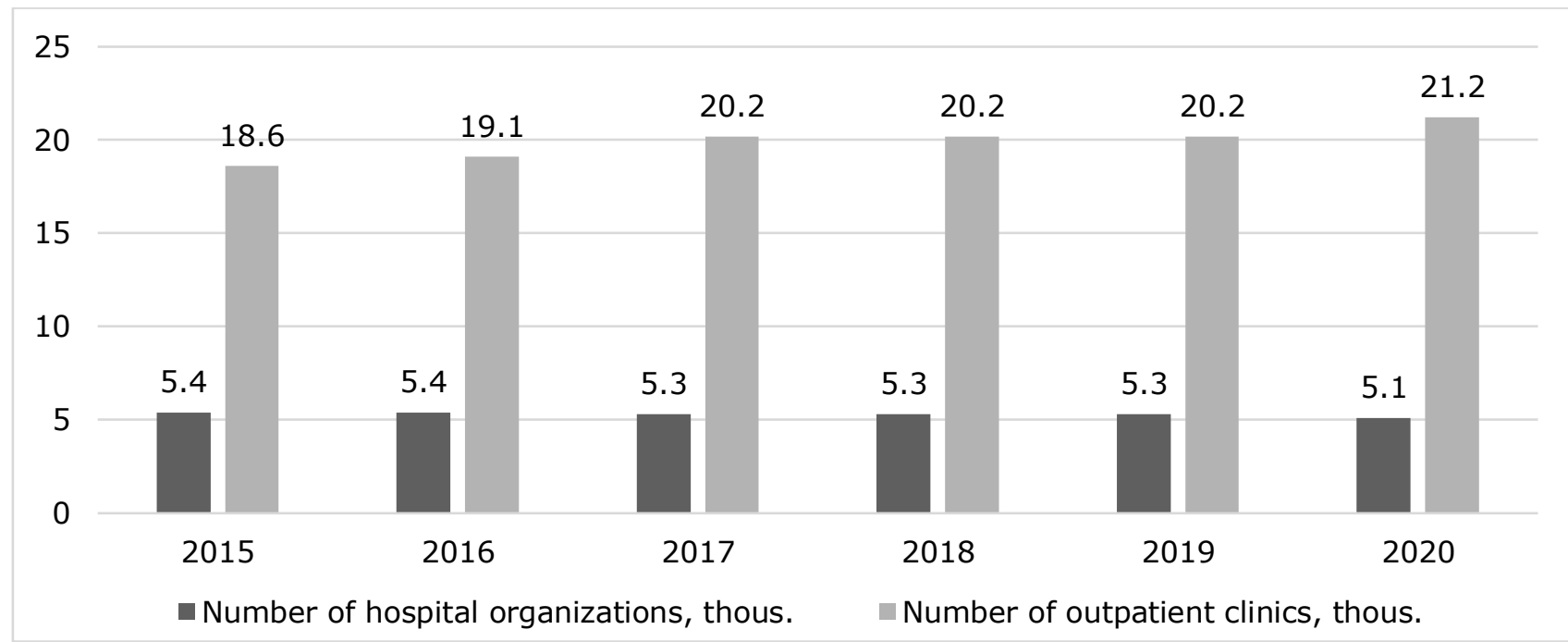

Source: compiled by the authors on the basis of data from Russia in numbers (2021).

Figure 5. Dynamics of the number of outpatient and hospital organizations in Russia in 2015-2020.

As a result, there is an increase in the throughput of polyclinics by more than $5 \%$ over the period under review, as a result of which the capacity of the outpatient polyclinic network of the country reached 4.1 million visits per shift in 2020, and 278 visits per shift per 10 thousand population, which is the highest value for the period under review. As a result, we can say that primary health care has been actively developing in recent years, while the availability of medical care for the population on an outpatient basis has increased significantly, since the number of visits per shift per 10 thousand people increased by 14 units. At the same time, the capacity of the country's hospital network providing inpatient care has decreased by almost 4\% in 5 years. If in 2015 the country's bed capacity was more than 1.22 million beds, then in the last 2 years the figure is at the level of 1.17 million beds. This is due to their reduction in the framework of resource optimization in the industry, since inpatient care is one of the most expensive, as well as the maintenance of one functioning bed. As a result of the reduction in the absolute number of beds in the country, the provision with beds decreased to 80 per 10 thousand of the population, while their number was 83 in 2015. Therefore, we can talk about a decrease in the provision of the population with beds, which indicates a decrease in the availability of this type of medical care. 
REVISTA DE LA UNIVERSIDAD DEL ZULIA. $3^{a}$ época. Año 12 N 34, 2021

Danil Alekseevich Zyukin et al// Poverty in Russia as the main threat to economic security ... 261-281

DOI: http://dx.doi.org/10.46925//rdluz.34.16

At the same time, it should be noted that not only health, but also in a number of cases, a person's life largely depends on the availability of inpatient medical care, since this type of care, in contrast to outpatient care, is characterized by the greatest functionality and allows you to receive high-tech medical services. Therefore, the transfer of the main load to the primary care cannot be considered an absolutely correct decision, which became clearly understood with the onset of the coronavirus pandemic. When there was an acute shortage of pulmonary beds in the country and difficulties in re-profiling other beds, taking into account the need of time, and also there was a need to expand the bed capacity in the country through the construction of additional capacities (Table l).

Table 1. Dynamics of the main indicators of the development of the healthcare system in Russia in 2015-2020.

\begin{tabular}{|c|c|c|c|c|c|c|c|}
\hline \multirow{2}{*}{ Index } & \multicolumn{6}{|c|}{ Value } & \multirow{2}{*}{$\begin{array}{c}\text { Change in } \\
2020 \text { to } \\
2015, \%\end{array}$} \\
\hline & 2015 & 2016 & 2017 & 2018 & 2019 & 2020 & \\
\hline \multicolumn{8}{|c|}{ Capacity of outpatient clinics, visits per shift: } \\
\hline total, thous. & 3861 & 3914 & 3967 & 3967 & 3998 & 4072 & 5,5 \\
\hline per 10 thousand people & 264 & 267 & 270 & 270 & 272 & 278 & 5,3 \\
\hline \multicolumn{8}{|c|}{ Number of hospital beds: } \\
\hline total, thous. & 1222 & 1197 & 1183 & 1183 & 1173 & 1174 & $-3,9$ \\
\hline per 10 thousand people & 83 & 82 & 81 & 81 & 80 & 80 & $-3,6$ \\
\hline
\end{tabular}

Source: compiled by the authors on the basis of data from Russia in numbers (2021).

The current state of the education sector is also characterized by a number of problems, primarily in the school sector. Over the past 6 years, the total number of schools decreased by $9 \%$ and amounted to 40.8 thousand compared to 44.8 thousand at the beginning of the period under review. At the same time, this reduction is due solely to the reduction of state and municipal schools by $9.4 \%$, while the number of private ones is steadily growing and by 2020 reached 857 units, although it makes up a small share in the total volume of schools in the country. In the sphere of secondary vocational education, there is a positive dynamics of growth in the number of functioning institutions: over 6 years, their number increased by $13.3 \%$ and reached almost 3.3 thousand, while only 2.9 thousand of them are state or municipal. One of the current trends in the field of secondary vocational education is the active growth in the number of private organizations of this profile: in just 6 years, their number has almost doubled and amounted to 362 units. Extremely negative 
REVISTA DE LA UNIVERSIDAD DEL ZULIA. $3^{a}$ época. Año 12 N$^{\circ}$ 34, 2021

Danil Alekseevich Zyukin et al// Poverty in Russia as the main threat to economic security ... 261-281

DOI: http://dx.doi.org/10.46925//rdluz.34.16

trends are observed in the field of higher education, where the overall decline in the number of higher educational institutions has exceeded 40\%. Despite the increase in the indicator in 2016 to 1079 units, by 2020 the number of higher educational institutions decreased to 563 units. At the same time, the reduction was most reflected in higher educational institutions of private ownership (-68.2\%), the total number of which was only 128 by 2020 , while the total number of state institutions was 435 , which is more than $20 \%$. below the base year level (Table 2).

Table 2. Dynamics of the main indicators of the development of the education system in Russia in 2015-2020

\begin{tabular}{|c|c|c|c|c|c|c|c|}
\hline \multirow[b]{2}{*}{ Index } & \multicolumn{6}{|c|}{ Value } & \multirow{2}{*}{$\begin{array}{c}\text { Change } \\
\text { in } 2020 \\
\text { to } 2015 \text {, } \\
\%\end{array}$} \\
\hline & 2015 & 2016 & 2017 & 2018 & 2019 & 2020 & \\
\hline Schools (total), incl:: & 44848 & 43376 & 42621 & 41958 & 41349 & 40823 & $-9,0$ \\
\hline state and municipal & 44097 & $\begin{array}{r}4259 \\
3\end{array}$ & 41804 & 41103 & $\begin{array}{r}4049 \\
8\end{array}$ & 39966 & $-9,4$ \\
\hline private & 751 & 783 & 817 & 855 & 851 & 857 & 14,1 \\
\hline $\begin{array}{l}\text { Organizations of } \\
\text { secondary vocational } \\
\text { education (total), incl.: }\end{array}$ & 2909 & 2891 & 3278 & 3316 & 3311 & 3295 & 13,3 \\
\hline state and municipal & 2665 & 2645 & 2995 & 2999 & 2961 & 2933 & 10,1 \\
\hline private & 244 & 246 & 283 & 317 & 350 & 362 & 48,4 \\
\hline $\begin{array}{l}\text { Higher education } \\
\text { organizations (total), } \\
\text { incl.: }\end{array}$ & 950 & 1079 & 840 & 651 & 596 & 563 & $-40,7$ \\
\hline state and municipal & 548 & 727 & 597 & 480 & 455 & 435 & $-20,6$ \\
\hline private & 402 & 352 & 243 & 171 & 141 & 128 & $-68,2$ \\
\hline
\end{tabular}

Source: compiled by the authors on the basis of data from Russia in numbers (2021).

As a result, we can say that negative social trends are also noted in the education sector, associated with a reduction in the number of institutions at all levels of education, except for secondary vocational, and in the largest state and municipal forms of ownership. This is largely due to the lack of funding for the education sector, as a result of which the maintenance and service of some educational organizations becomes impossible, and therefore, measures are being taken to optimize and reorganize. In the sphere of higher education, such a decrease is not so critical, since this level of education is not compulsory, although it is becoming more and more important; however, in the sphere of general (school) 
REVISTA DE LA UNIVERSIDAD DEL ZULIA. $3^{a}$ época. Año 12 N 34, 2021

Danil Alekseevich Zyukin et al// Poverty in Russia as the main threat to economic security ... 261-281 DOI: http://dx.doi.org/10.46925//rdluz.34.16

education, such tendencies are extremely negative, due to the obligatoryness and importance of this level of education for the formation of human potential with a high level of general literacy. A decrease in the number of schools inevitably contributes to the overcrowding of the remaining ones, which negatively affects the quality of the educational process and the final result of training.

In the context of the emerging budgetary educational infrastructure deficit and the trend towards the commercialization of education, especially higher education, preconditions are being formed for the active development of private educational organizations as a business area, similar to the healthcare sector. However, one of the main factors hindering the more active development of private systems of both education and health care today is hampered by the general low standard of living of the population and a decrease in real incomes, which often makes it impossible to obtain these types of services on a paid basis.

This is confirmed by the results of a comparative analysis of the main indicators of the standard of living in Russia and individual European countries, which underlines the existence of significant differentiation. Today, the country's living wage is one of the lowest and in 2020 amounted to \$321, which is almost equal to the level of Poland (\$322) and slightly below the level of the Czech Republic (\$359). At the same time, in the most developed European countries, such as the Netherlands, Great Britain, France, Italy and Germany, the size of the living wage of a person is more than 2 times higher than that of the Russian Federation.

Also extremely low in Russia can be noted and the minimum wage, which partly forms the initially low standard of living in the country. So, in 2020, the minimum wage in the Russian Federation amounted to $\$ 189$ per month, while in the Netherlands this figure is $\$$ 1,916, in Germany - \$1,784, Great Britain - \$1,740, and France - \$1,670., which forms an almost tenfold gap in the country in terms of wages in comparison with the most socially and economically developed countries in Europe.

The situation is similar with the average wage level: in Russia in 2020, the national average wage level was $\$ 592$, while in comparable European countries this indicator exceeds $\$ 1,000$. At the same time, the highest wage level in 2020 was celebrated in Germany (\$4090), France (\$3923) and the Netherlands (\$3096); more than \$2,000 per month average wages 
REVISTA DE LA UNIVERSIDAD DEL ZULIA. $3^{a}$ época. Año 12 N 34, 2021

Danil Alekseevich Zyukin et al// Poverty in Russia as the main threat to economic security ... 261-281

DOI: http://dx.doi.org/10.46925//rdluz.34.16

in countries such as the UK, Spain and Italy. As a result, it can be concluded that the average level of wages in Russia is low and significantly differentiated from the level of European countries, with the gap varying from 2 to 7 times (Figure 5).

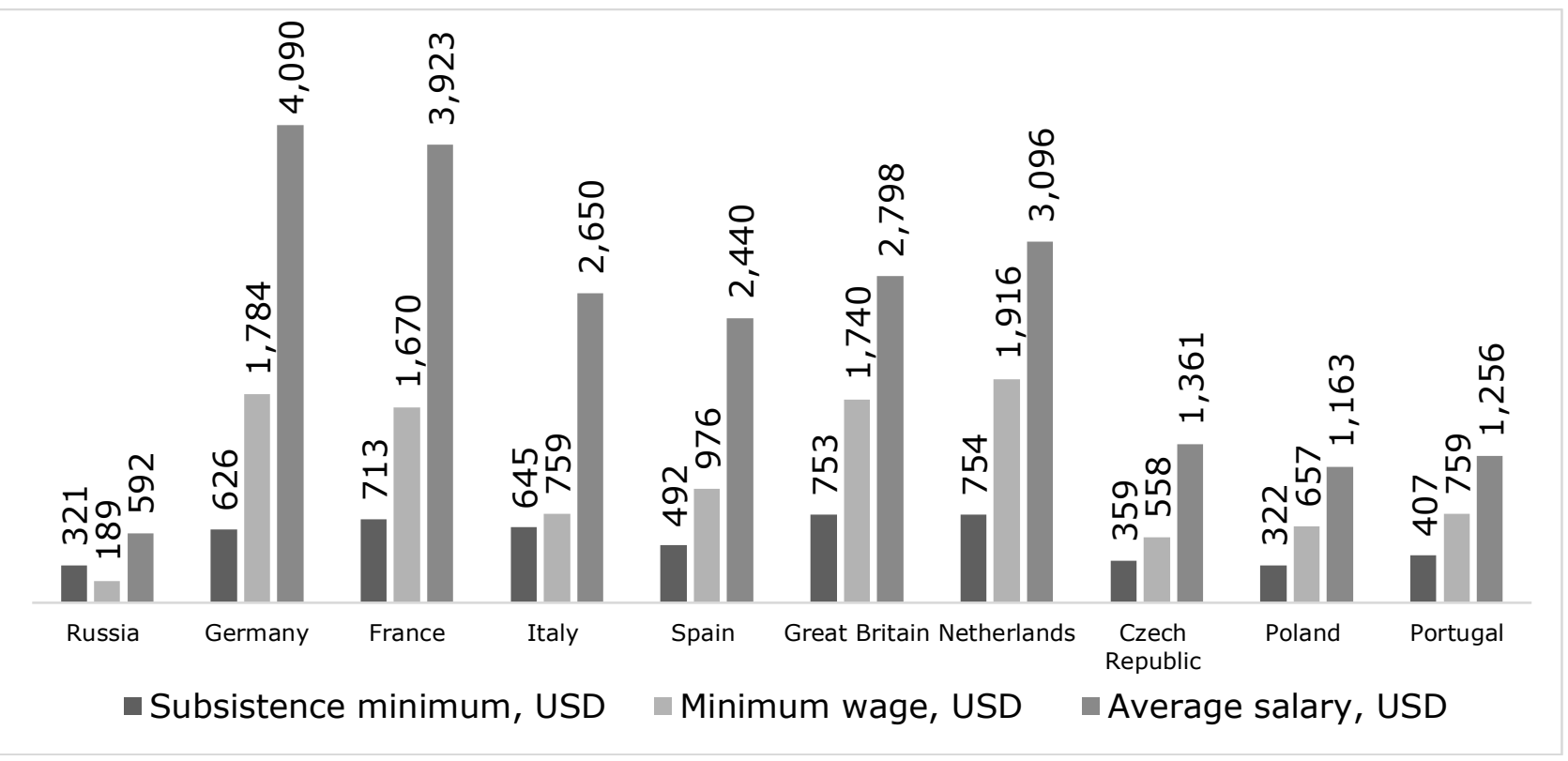

Source: compiled by the authors on the basis of data from Russia in numbers (2021).

Figure 5. Comparison of the main indicators of living standards in Russia and individual European countries in 2020.

Comparing the unemployment rate in Russia, which in 2020 was $5.5 \%$, and in European countries, we can note the presence of a significant variation in the indicator. So, the lowest unemployment rate is in the Czech Republic, Poland, Germany and Great Britain, where the indicator does not exceed 4\%. In turn, the highest level is observed in Spain, Italy and France, where the share of the unemployed population is more than $14 \%$, despite the relatively high level of wages in them. This indicates that the problems in the labor market in these countries are caused by factors other than the level of wages and may be associated with limited labor supply.

Considering the poverty level in the compared countries, it can also be noted that there is a significant variation in the indicator. Thus, the poverty level in Russia was 12.9\% in 2020, which is a fairly high value, but at the same time lower than the level of many European countries, such as Portugal, Poland, Spain and France. The lowest poverty rates are found in the Netherlands (less than 1\%), Germany (1.6\%), while the average is in Italy and the UK. At the same time, it can be noted that in some European countries, such as France and Italy, 
REVISTA DE LA UNIVERSIDAD DEL ZULIA. $3^{a}$ época. Año 12 N 34, 2021

Danil Alekseevich Zyukin et al// Poverty in Russia as the main threat to economic security ... 261-281

DOI: http://dx.doi.org/10.46925//rdluz.34.16

despite the presence of high minimum and average wages, as well as a living wage, the unemployment and poverty rates are also quite high, which allows us to conclude that that poverty as a phenomenon is a multidimensional problem that requires an integrated approach. At the same time, the experience of countries such as the Netherlands and Germany shows that the formation of a low level of unemployment and poverty while ensuring high indicators of the average level of wages takes place (Figure 6).

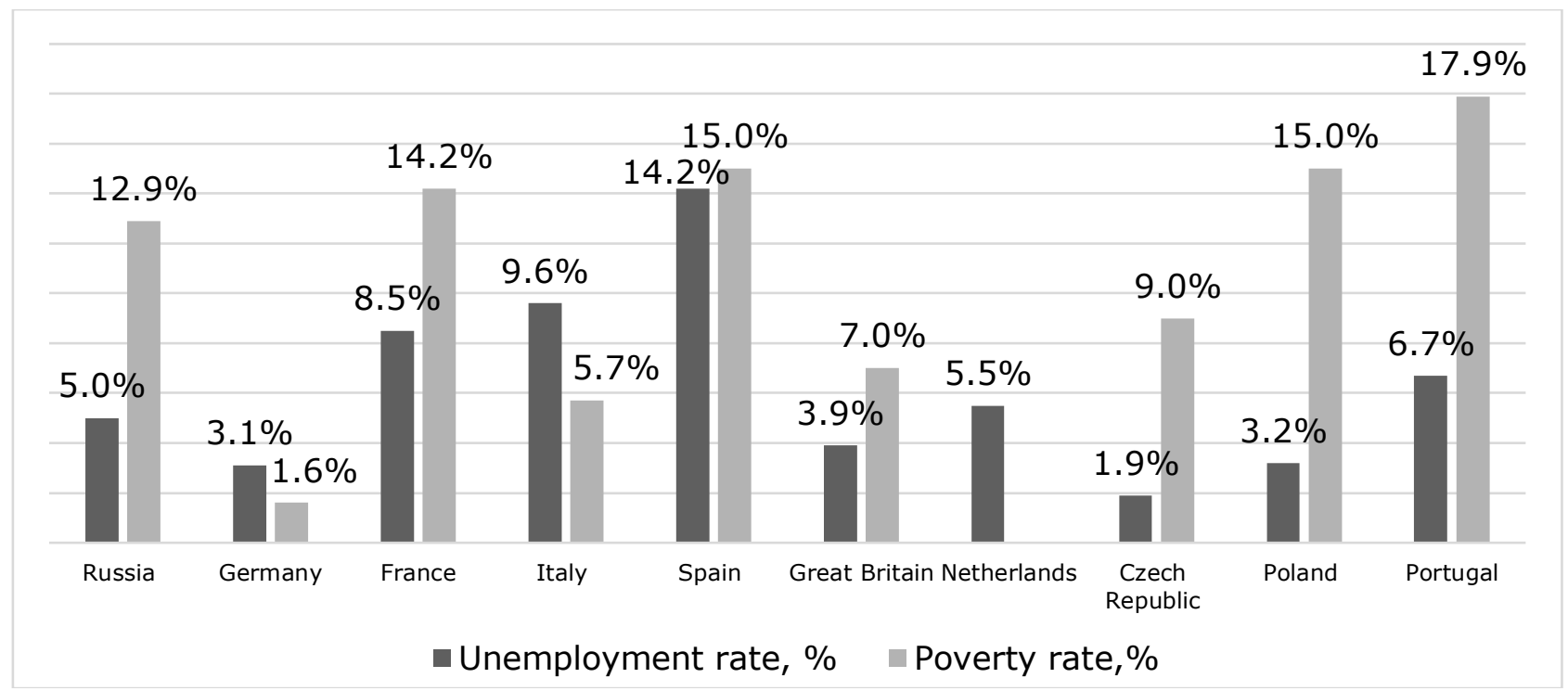

Source: compiled by the authors on the basis of data from Russia in numbers (2021).

Figure 6. Comparison of unemployment and poverty rates in Russia and selected European countries in 2020.

Evaluating the quality of life index as a summary criterion of socio-economic wellbeing in countries, it can be noted that Russia has the lowest value of 5.31, while in the considered European countries this indicator varies within 6.66-7.94, which forms a gap at the level of $25-50 \%$. At the same time, the highest value of the quality of life index is observed in the Netherlands and Germany, which occupy leading positions in all considered socioeconomic indicators. In turn, the lowest values among the EU countries are noted in Poland and Portugal, but, however, they significantly exceed the level formed in the Russian Federation. As a result, it can be concluded that today in Russia the level of quality of life is rather low and significantly inferior to the level of most European countries, which is due to the existing socio-economic problems, the main of which is poverty and the trend towards a decrease in real incomes of the population in recent years (Figure 7). 
REVISTA DE LA UNIVERSIDAD DEL ZULIA. $3^{a}$ época. Año 12 N 34, 2021

Danil Alekseevich Zyukin et al// Poverty in Russia as the main threat to economic security ... 261-281

DOI: http://dx.doi.org/10.46925//rdluz.34.16

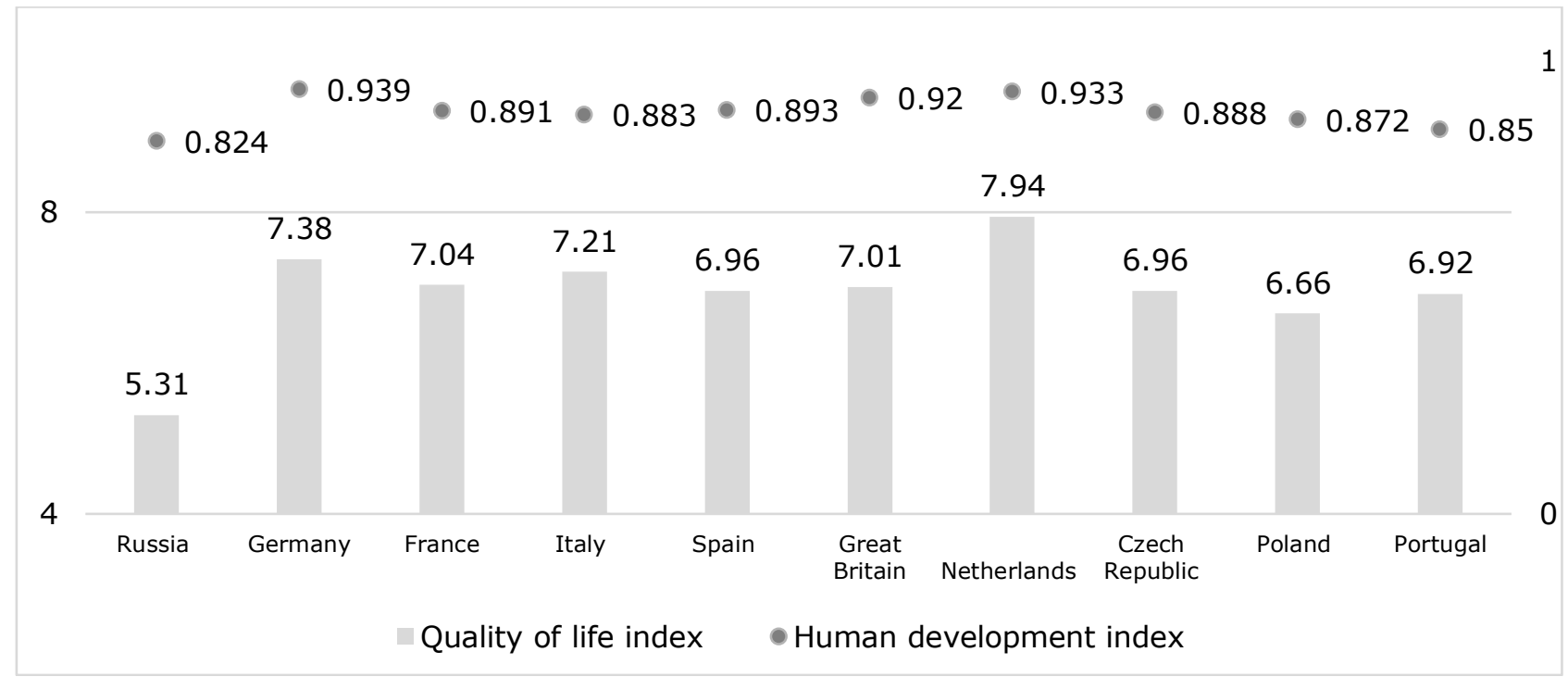

Source: compiled by the authors on the basis of data from Russia in numbers (2021).

Figure 7. Comparison of quality of life and human development indices in Russia and individual European countries in 2020

The study of the human development index in 2020 in Russia in comparison with European countries revealed that in all the countries under consideration, in accordance with the adopted methodology, the level of the human development index is high, since it exceeds 0.800. At the same time, it should be noted that among all the studied countries, Russia has the lowest indicator of 0.824 , while in the most socially and economically prosperous Germany and the Netherlands, the indicator was 0.939 and 0.933, respectively. Also, more than 0.9 human development index is noted in the UK, and within 0.85-0.9 - in the remaining of the considered European countries. As a result, it can be concluded that the level of socioeconomic well-being of the population existing in Russia today is rather low in comparison with the level of the leading European countries.

\section{Discussion}

The problem of poverty is one of the most pressing and significant for many years in Russia and unfavorable economic factors of recent years have contributed to an even greater deterioration in the material situation of the population (Klimanov, 2020), as a result of which the poverty level, which was already at a sufficiently high level, has returned grow (Malkina, 2016). Modern Russian society is characterized by significant social stratification, which tends to increase, as a result of which a significant part of the population continues to become impoverished, while the other continues to become more and more rich (Mikheeva, 
REVISTA DE LA UNIVERSIDAD DEL ZULIA. $3^{a}$ época. Año 12 N 34, 2021

Danil Alekseevich Zyukin et al// Poverty in Russia as the main threat to economic security ... 261-281

DOI: http://dx.doi.org/10.46925//rdluz.34.16

2020). The indices of consumer expectations and consumer confidence over the past years have been negative values, which indicates the predominance of negative assessments of the personal financial situation by the population (Shuvalova, 2018).

In addition, it should be noted that the very method of determining the "poverty line", which allows the population to be graded by income level, is rather relative and does not correspond to the realities in Russia (Orlova and Lavrova, 2020). Today, the key indicator is the subsistence minimum, determined in accordance with the consumer basket, which, according to many researchers (Shirov, 2021; Pasechko and Sapronov, 2017), is nominal and does not correspond to the price level in the economy, as well as to all the basic needs of a modern person. As a result, the official poverty level in the country is quite high, despite the fact that only the population with the lowest income is taken into account in the calculation; despite the fact that a significant proportion of people have incomes, although higher than the subsistence level, but also low enough for a comfortable life (Slobodenyuk and Anikin, 2018). One of the solutions to the problem is the idea of switching to an unconditional basic income, which is being implemented as an experiment in Finland (Stefanova and Shchukin, 2017).

The current situation in Russia, according to a number of authors (Bobkov and Odintsova, 2020; Korovkin, 2018), is caused, among other things, by problems in the labor market associated with a significant imbalance between supply and demand, as well as with the overall low cost of human labor for market. As a result, people often lack decent employment opportunities with adequate wages, especially in a number of occupations that are less attractive (Lialina, 2021). Among the factors, the most significant risk factors for working income poverty were: female gender, the number of household members, work experience at the current place of work, the presence of disability, unwillingness to work additionally, even if it will bring additional income, the availability of secondary special, vocational and technical education (Aslayeva et al, 2021).

The situation is such that in the regions of the country the level of remuneration is formed differentially and is directly dependent on the socio-economic development of the territory (Parkhomchuk et al., 2021; Borovitskaya et al, 2019). The situation in the labor market is aggravated by the presence of territorial differentiation in the level of wages, which activates the processes of labor migration in the economy and thereby creates a shortage of 
personnel in less attractive regions of the country (Mkrtchyan and Florinskaya, 2018). As a result, there is an increase in social inequality between the regions of the country, where the level of wages and living in general is observed in economic centers, while in the remote peripheral regions of the country the level of poverty is higher (Smirnyh and Polyakova, 2020).

Therefore, at the present stage, the central task within the framework of the strategy for the long-term socio-economic development of Russia is not only a qualitative increase in the level of well-being of the population, but also the smoothing of the emerging territorial interregional disparities in the level of wages (Berdiev et al., 2020). This will create a favorable living environment everywhere and thereby reduce poverty (Kolosnitsina and Filippova, 2017).

\section{Conclusions}

The problem of poverty is still one of the most pressing and urgent for modern Russia. Despite the outlined positive dynamics in the poverty level of the country's population in 2018-2019, there was a decline again in 2020, due to the deterioration of the socio-economic situation against the backdrop of the coronavirus pandemic. As a result, the effectiveness of earlier measures within the framework of social policy has practically disappeared, and the poverty level has practically reached $13 \%$, which in absolute terms amounted to 18.8 million people. Separately, it is worth highlighting inflation and the level of prices in the country: despite the systematic growth of the nominal average per capita income of the population to 35.7 thousand rubles at an official low level of inflation, the situation is such that the real income of the population changes abruptly, and decreased by $4 \%$ in 2020 relative to the level of the previous year. All this indicates that there is no qualitative increase in the level of wellbeing of the Russian population, which is associated with the general unfavorable situation in the country. The deterioration of the financial situation is also confirmed by the results of sociological surveys of the population, as a result of which almost $40 \%$ of the respondents noticed a deterioration in their financial situation in 2020. In addition, in 2020, about 40\% of the population noted a moderate increase in prices, and in 2021, more than $50 \%$ considered that prices increased significantly. Taking into account the fact that the real incomes of the population are decreasing, and the nominal ones are growing at a low rate, an increase in 
prices in the economy inevitably leads to a decrease in the level of material provision of the population, since there is a decrease in the volume of goods and services that can be purchased for a specific amount.

In addition to negative trends in the sphere of financial support of the population, negative trends are also highlighted in the sphere of social policy. The systemic lack of financial support for such critical sectors as education and health care has contributed to a series of cuts in order to save limited resources. As part of the modernization program, the number of schools and higher educational institutions in the country has decreased, although the total number of secondary vocational organizations is growing. Also, one of the main trends at the current stage is the active development of private educational institutions, which is largely due to the inadequacy of the budget system to meet the needs of the population in educational services. At the same time, in the conditions of a decrease in real incomes of the population, a decline in demand for private educational services is also natural, due to their high cost. A comparative analysis of the main socio-economic indicators in Russia and European countries revealed the existence of significant differentiation. In terms of the subsistence minimum, the minimum wage and average wage, Russia occupies the last positions among the compared countries, and the differentiation in comparison with the most developed Germany is 2, 9 and 7 times for these indicators, respectively. The unemployment and poverty rates in Russia are not the highest in comparison with other countries, but they are higher in comparison with the most developed countries such as Germany and Great Britain. At the same time, it should be noted that these indicators cannot be considered unconditional and the only indicators for assessing the socio-economic situation, since in a number of countries where the level of unemployment and poverty is nominally higher, such as in France and Spain, the general level and quality lives are more auspicious. This is confirmed by a comparison of the indices of the quality of life and human development in the countries under consideration, where the lowest values are also noted in Russia. This indicates that the current socio-economic situation in the country is not favorable, and the standard of living remains rather low in comparison with European countries.

The problem of poverty and low living standards at the current stage of the socioeconomic development of Russia is becoming increasingly important, since the negative 
REVISTA DE LA UNIVERSIDAD DEL ZULIA. $3^{a}$ época. Año 12 N 34, 2021

Danil Alekseevich Zyukin et al// Poverty in Russia as the main threat to economic security ... 261-281

DOI: http://dx.doi.org/10.46925//rdluz.34.16

trends of the last year associated with the coronavirus pandemic have exacerbated the existing imbalances. As a result, the real incomes of the population decreased, there was a jump in the unemployment rate, as the pandemic dealt a significant blow to business. Under these circumstances, the role of the state and its participation in supporting the population and business is significantly increasing. However, the measures taken to date are mostly nominal and do not have a significant positive impact on the current situation. Support for the population in the form of lump-sum payments for families with children is more tangible, but it is practically nonexistent for business. The reduction in tax rates for the most affected industries, although it is a certain relaxation, is not the most necessary tool in the context of a crisis and the disruption of most production and economic ties, since the economy is inefficient and revenue is low or absent. As a result, the key task at the current stage is to reduce inflation and support the economy in order to ensure the rates of pre-crisis economic growth. The payment of benefits to the population cannot be permanent, therefore it is necessary to create all conditions for the formation of a favorable situation in the labor market and the possibility of obtaining a higher income. This, in turn, is directly dependent on the efficiency of business processes in the economy, in connection with which the current situation requires an integrated approach at the highest level, since the possibilities for further economic growth and development of the country depend on this.

\section{References}

Aslayeva S.Sh., Gaisina A.Sh., Karimov A.G. (2021) Econometric analysis of working population poverty factors. Azimut of scientific research:economics and manage, 2 (35), 65-68.

Berdiev, A.N., Saunoris, J.W. \& Schneider, F. (2020). Poverty and the shadow economy: The role of governmental institutions. World Econ., 43, 921-947.

Bobkov V.N. \& Odintsova E.V. (2020). Social inequality in Russia. Journal of the New Economic Association, 3 (47), 179-183.

Borovitskaya, M. V., Strelnikov, E. V., Khayrullina, R. G., Kolesnikov, M. A., \& Mukhniuk, M. I. (2019). A basis for regional competitiveness: socio-economic potential. Revista De La Universidad Del Zulia, 10 (28), 345-356.

Chu, C.-Y., \& Jiang, M. (2021). Financial depth, income inequality, and economic transition. Southern Economic Journal, 1- 46. 
REVISTA DE LA UNIVERSIDAD DEL ZULIA. $3^{a}$ época. Año 12 N 34, 2021

Danil Alekseevich Zyukin et al// Poverty in Russia as the main threat to economic security ... 261-281

DOI: http://dx.doi.org/10.46925//rdluz.34.16

Datt, G., Ravallion, M. \& Murgai, R. (2020). Poverty and Growth in India over Six Decades. Amer. J. Agr. Econ., 102, 4-27.

Gnangnon, SK. (2021). Poverty volatility and poverty in developing countries. Economic Affairs, 41, 84-95.

Hussain, S., Hali, S. M., Ahmad, R., Iqbal, S., \& Iftikhar, H. (2021). Fiscal decentralization and poverty alleviation: A case study of Pakistan. Poverty Public Policy, 1- 16.

Klimanov, V.V., Kazakova, S.M. \& Mikhaylova, A.A. (2020). Economic and Fiscal Resilience of Russia's Regions. Reg Sci Policy Pract., 12, 627- 640.

Kolosnitsyna M.G. \& Filippova A.V. (2017). Child benefits and poverty in Russia. Economic Policy, Vol. 12, 4, 118-153.

Korovkin A.G. (2018). Macroeconomic assessment of the state and development prospects of the employment sector and the labor market in Russia. Journal of the New Economic Association, $1(37), 168-176$.

Lialina, A.V. (2021). Migrant workers in labour markets of Russian western borderlands. Int Migr.

Malkina M.Yu. (2016). Assessment of the social welfare of Russian regions, the level and dynamics of interregional differences based on welfare functions. Terra Economicus, Vol. 14, 3, 29-49.

Measuring inflation expectations and consumer sentiment based on public opinion polls for June 202l. Available at: https://cbr.ru/Collection/Collection/File/35446/inFOM_2l-06.pdf (accessed 07/01/2021)

Mikheeva, N. (2020). Qualitative Aspect of the Regional Growth in Russia: Inclusive Development Index. Reg Sci Policy Pract., 12, 611-626

Mkrtchyan N.V. \& Florinskaya Yu.F. (2018). Labor migration in Russia: international and domestic aspects. Journal of the New Economic Association, 1 (37), 186-193.

Orlova N.V. \& Lavrova N.A. (2020). Russian middle class: structural features and financial behavior. Economic Issues, 11, 32-46.

Parkhomchuk M. A., Gryaznova O. A., Grebneva M. E., Vinogradova N. I. (2021) The problem of differentiation of the level of remuneration in the regions of the Central federal district. Azimut of scientific research: economics and management, 1 (34), 247-250.

Pasechko L. \& Sapronov A. (2017). Poverty in Russia: theoretical and methodological issues of research. Economic Journal-XXI, T. 165, 5-6, 27-30.

Russia in Numbers, 2021: Brief statistical collection. Rosstat-M., 2021, 275. 
REVISTA DE LA UNIVERSIDAD DEL ZULIA. $3^{a}$ época. Año 12 N 34, 2021

Danil Alekseevich Zyukin et al// Poverty in Russia as the main threat to economic security ... 261-281

DOI: http://dx.doi.org/10.46925//rdluz.34.16

Shirov, A. A. (2021). Pandemic economic crisis: development mechanisms and solutions in the field of economic policy. Journal of the New Economic Association, 1 (49), 209-216.

Shuvalova O. V. (2018) Standard of living and quality of life: factors and russian specifics. Azimut of scientific research:economics and management, 1 (22), 276-279.

Slobodenyuk E.D. \& Anikin V.A. (2018). Where is the "poverty line" in Russia? Economic Issues, $1,104-127$.

Smirnykh L.I. \& Polyakova E.Yu. (2020). Labor income and the integration of migrants in the Russian labor market. Journal of the New Economic Association, 3 (47), 84-105.

Stefanova N.A., Shchukin K.A. (2017) Unconditional basic income: to be or not to be. Karelian Scientific Journal, 4 (21), 309-311.

Zyukin, D.A., Bystritskaya, A.Yu., Golovin, A.A. \& Vlasova O.V. (2020a). The share of health care spending in the structure of GDP as a criterion for the healthcare system effectiveness. Año $11 \mathrm{~N}^{\circ}$ 30, 352-363.

Zyukin, D.A., Oleinikova, T.A., Evstratov, A.V., Sergeeva, N.M., Reprintseva, E.V., Ulyanov, V.O. (2020b). Higher Pharmaceutical Education in Russia: Economic Assessment of Accessibility and Regional Specifics. SRP, 11(2), 317-328. 